\title{
Antioxidant and Antimicrobial Effect of Oregano Essential Oil on Shelf-Life of Chicken Patties
}

\author{
Neha Thakur ${ }^{1,2 *}$, S.K. Mendiratta ${ }^{2}$, Geeta Chauhan ${ }^{2}$, Arvind Soni ${ }^{2}$ and \\ Ravi Kant Agrawal ${ }^{2}$ \\ ${ }^{1}$ PGIVER, RAJUVAS, India \\ ${ }^{1}$ Division of Livestock Products Technology, ICAR-Indian Veterinary research institute, \\ Bareilly-243122, U.P., India \\ *Corresponding author
}

\begin{abstract}
A B S T R A C T
\section{Keywords}

Oregano essential oil, Antimicrobial effect, Antioxidant effect, Sensory

Article Info

Accepted:

22 January 2019

Available Online:

10 February 2019

The present study was envisaged to study the antioxidant and antimicrobial potential of oregano essential oil (OEO) in processed meat model (chicken patties, CP). Three treatments were prepared as control (CP without CEO), T-1, T-2 and T-3 containing $0.125 \%, 0.25 \%$ and $0.5 \%$ OEO, respectively and aerobically packaged. The samples were evaluated for different quality attributes. Results pointed out that the T-3 product had the highest oxidative and antimicrobial potential out of all products as predicted by lowest thiobarbituric acid reacting substances and highest 1, 1 diphenyl-2 picrylhydrazyl radical scavenging activity with lowest microbial load followed by T-2, T-1 and control. on the other hand, sensory scores of T-3 were lesser than that of others, showing some pungency. The control product got spoiled on $21^{\text {st }}, \mathrm{T}-1$ and T-2 on $25^{\text {th }}$ and T-3 on $30^{\text {th }}$ day of storage. In conclusion, $0.125 \%$ OEO can be efficiently incorporated in products without affecting sensory attributes.
\end{abstract}

\section{Introduction}

Chicken meat and products are widely consumed all over the world. They have many desirable nutritional characteristics such as low lipid contents and relatively high concentrations of polyunsaturated fatty acids, which can be further enhanced by specific dietary strategies (Bourre, 2005). However, a high degree of polyunsaturation accelerates oxidative processes leading to deterioration in meat flavor, color, texture and nutritional value (Mielnick, et al. 2006). To prevent these effects antioxidants are used which can be either synthetic or of natural origin. Synthetic antioxidants have been used popularly in meat and meat products namely butylated hydroxytoluene BHT, butylated hydroxyanisole BHA, propyl galate $\mathrm{PG}$ and tertiary butyl hydroquinone TBHQ but they have been found to cause adverse impact on human health (Barlow, 1990; Branen, 1975; Chan, 1987; Namiki, 1990; Pokorny, 1991). 
The antioxidant potential of oregano essential oil varies at different concentration (Koleva et al., 2002). It also would vary according to the nature of product in which it is being used, method adopted for cooking and cooking temperatures attained during the process, storage conditions maintained and the methods adopted for evaluation the antioxidant activity of the oil in question. The use of different concentrations of same oil would help us reach the accurate conclusion by correlating the results so obtained as a result of our different treatments to the same product.

It is known that the oregano essential oil inhibits hydroperoxide formation and that the CHO fraction showed the highest antioxidative activity. The antioxidant effect is due to the presence of thymol and carvacrol, but a possible synergistic effect among oxygen containing compounds can also be suggested (Milos et al., 2000) the use of this oil finished meat products has been made at very low levels (Chouliara et al.,2007) but the activity of this wonder oil has potential which is still lies unharnessed, waiting to be discovered and isolated studies with oregano oil as the leading factor in spoilage studies is yet to be undertaken. Doing so will throw the much needed light on its remarkable powers at natural antioxidant and also bring its antimicrobial properties into limelight. This small study is an attempt to do so and aim at application of the prowess of oregano essential oil in finished meat product industry which has taken the food industry by storm due to increase demand in pre-cooked/ ready-to-eat meat products that can gel well with the modern and healthy lifestyle choices.

Considering all these factors the main aim of the present study was to investigate: (a) the potential of Oregano oil to avert spoilage (lipid peroxidation) in chicken patties stored at $5^{\circ} \mathrm{C} \quad$ (b) effect of varying concentrations $(0.125 \%, 0.25 \%, 0.50 \%)$ of oregano essential oil on microflora (TPC, Coliform count) of the product prepared (c) evaluation of the incorporation level of oil (concentration to be used) that meets effective (in terms of antioxidant and bacteriostatic effect) as well as acceptable levels (in terms of sensory evaluation).

\section{Materials and Methods}

\section{Raw materials}

\section{Chicken meat}

Dressed spent hens were procured from Central Avian Research Institute (CARI), Izatnagar within $4 \mathrm{~h}$ of slaughter. These carcasses were brought to abattoir of LPT Division, IVRI and manually deboned and trimming of tendons, separable connective tissue and body fat was also done under hygienic conditions. Chicken meat obtained was packaged in clean low density polyethylene bags (200gauge) and kept for conditioning in a refrigerator at $4{ }^{\circ} \mathrm{C}$ for about $24 \mathrm{~h}$. Thereafter, the samples were transferred and kept in deep freezer (Blue Star, FS345, Denmark) for storage at $-18 \pm 2{ }^{\circ} \mathrm{C}$ till further use. Cellulose casings (C17 9 84ft.) were purchased from Euromate Food Tech. Pvt. Ltd., New Delhi.

\section{Essential oils and non meat ingredients}

Food grade essential oils were purchased from reputed commercial suppliers. Refined salt (Tata Salt, Tata Chemicals Ltd., Mumbai) was purchased from local market of Bareilly. Food additives incorporated in the formulations were of food grade quality and procured from reputed firms i.e., sodium nitrite (Merck Specialities Pvt. Ltd., Mumbai), sodium tripolyphosphate (Central Drug House Pvt. Ltd., (CDH) New Delhi). 


\section{Chemicals}

All the chemicals and reagents for laboratory analysis of chicken patties were of analytical grade and procured from standard firms viz, Qualigens, GS chemicals, Sigma, CDH and Merck. The culture media and their additives used in the study were procured from Himedia Laboratories, Mumbai.

\section{Packaging materials}

Linear low density polyethylene films (200 gauge) used for aerobic packaging of the products were purchased from local market of Bareilly.

\section{Processing of fresh chicken patties}

Fresh chicken patties were prepared by mixing various ingredients in a mixer (Table 1). The frozen meat was partially thawed at refrigeration temperature $\left(4 \pm 1^{\circ} \mathrm{C}\right)$ for about 16-18 $\mathrm{h}$ and cut into intact pieces. It was divided into different batches (500 $\mathrm{g}$ each) for control and treatments. The treatments included applying three varying concentrations of the same E.O., i.e. $0.125 \%$, $0.25 \%$ and $0.50 \%$. After the mixing of E.O. to the meat, all ingredients were mixed and emulsion was made in bowl chopper. After that the emulsion was given shape of patties after accurately weighing $70 \mathrm{~g}$ of emulsion for each patty. The patties were cooked in hot air oven to an internal temperature of $72^{\circ} \mathrm{C}$ and temperature was monitored using a probe thermometer (digital thermometer, WT-1, China). The patties were cooled off and packed in LDPE pouches and stored at $4{ }^{\circ} \mathrm{C}$.

\section{Detailed study}

Physico-chemical qualities viz, $\mathrm{pH}$, TBARS value, anti-oxidant activity ( DPPH radical scavenging activity), sensory attributes (cooked product) and microbiological characteristics (total plate count, Coliforms count) were assessed on $0,3,5,10,15$ and 20 days in aerobically packaged products.

\section{Physico-chemical analysis}

\section{Yield (in percent)}

Yield of chicken sausages was calculated on percent basis based on weight of sausages before cooking which is given below:

Percent $(\%)$ cooking yield $=$

Weight of sausages after cooking X $100 \%$

Weight of sausages before cooking

\section{pH}

$\mathrm{pH}$ of chicken sausages was determined as per the procedure of Troutt et al., (1992). $10 \mathrm{~g}$ of sample was blended with $50 \mathrm{ml}$ of distilled water for $1 \mathrm{~min}$ using an Ultra Turrax tissue homogenizer (Model IKAT 18, Janke and Kenkel, IKA Labor Technik, Germany). The $\mathrm{pH}$ of the homogenate was recorded by immersing a combined electrode of a digital pH meter (Model CP 901, Century Instrument Ltd. India).

\section{Thiobarbituric acid reactive substances (TBARS) number}

The extraction method described by Witte $e t$ al (1970) was used with suitable modifications for the determination of TBARS value in CME and CMC. $10 \mathrm{~g}$ of sample was triturated with $25 \mathrm{ml}$ of precooled $20 \%$ trichloroacetic acid (TCA) in $2 \mathrm{M}$ orthophosphoric acid solution for $2 \mathrm{~min}$. The content was then quantitatively transferred into a beaker by rinsing with $25 \mathrm{ml}$ of cold distilled water, mixed properly and filtered through ashless filter paper (Whatman filter paper No. 1 supplied by s. d. Fine Chemicals Ltd., Mumbai, India). Then $3 \mathrm{ml}$ of TCA 
extract (filtrate) was mixed with $3 \mathrm{ml}$ of TBA reagent $(0.005 \mathrm{M})$ in test tubes and placed in a dark room for $16 \mathrm{hrs}$. A blank sample was made by mixing $1.5 \mathrm{ml}$ of $20 \%$ TCA, $1.5 \mathrm{ml}$ distilled water and $3 \mathrm{ml}$ of $0.005 \mathrm{M} \mathrm{TBA}$ reagent. Absorbance (O.D.) was measured at fixed wavelength of $532 \mathrm{~nm}$ with a scanning range of $531 \mathrm{~nm}$ to $533 \mathrm{~nm}$ using UV-VIS spectrophotometer (Elico SL-159, Mumbai, India). TBARS number was calculated as $\mathrm{mg}$ malonaldehyde per $\mathrm{kg}$ of sample by multiplying O.D. value with a factor 5.2.

\section{DPPH radical scavenging activity}

Measurements with the DPPH assay were taken using a method used by Tepe et al., (2005). $0.1 \mathrm{~g}$ of the samples and $5 \mathrm{ml}$ of $0.004 \%$ DPPH in methanol were added to a test tube. The samples were subjected to homogenization for $30 \mathrm{~s}$ using Ultra Turrax tissue homogenizer (Model IKA 18, IKA Labor Technik, Germany). The samples were kept at room temperature for $30 \mathrm{~min}$ with constant mixing. Absorbance was measured using spectrophotometer (Model: Beckman DU 640, USA) at $517 \mathrm{~nm}$. Methanol was used as a blank and measurements were expressed as absorbance. Decrease in absorbance indicated increased antioxidant activity level of the essential oils.

\section{Microbiological analysis}

Standard plate count (SPC), pyschrotrophic counts, coliforms counts and yeast and mold counts of the samples were enumerated following the methods as described by American Public Health Association (APHA, 1992).

\section{Sensory evaluation}

Sensory attributes for chicken sausages were evaluated using an eight point descriptive scale (Keeton 1983) where 8 score was given for an excellent product and 1 was for extremely poor product. The sensory panelists consisted of scientists and post graduate students of Livestock Products Technology Division of IVRI. The panelists were briefed about the nature of the experiments without disclosing the identity of the samples. The samples were served warm $\left(40-60^{\circ} \mathrm{C}\right)$ by preheating the samples in microwave oven (LG Model MC-7148 MS, 1200 W microwave power, India) for $2 \mathrm{~min}$ and sensory evaluation was conducted around 3.30-4 pm. Panelists were requested to evaluate using sensory evaluation proforma for different attributes such as general appearance, flavour, binding, texture, juiciness and overall acceptability of the product. Plain water was provided to rinse the mouth between tasting of each sample.

\section{Results and Discussion}

\section{Proximate composition}

The inspection of results revealed that inclusion of oregano essential oil did not affect the moisture, fat, protein and ash content of all samples (Table 2). No significant $(\mathrm{P} \leq 0.05)$ difference in mean moisture, fat, protein and ash content of chicken patties was observed.

\section{pH}

The Mean \pm S.E. values of $\mathrm{pH}$ during refrigerated storage of the aerobically packaged enrobed products are given in table 3. During storage, $\mathrm{pH}$ followed an increasing trend throughout the storage period in all the samples, although the rate of increase was slower in case of EO treated products. The meat spoilage indicated by rise in $\mathrm{pH}$ is due to the breakdown of the protein components (Karabagias et al., 2011). The closer analysis of findings indicated that the $\mathrm{pH}$ changed significantly $(\mathrm{P} \leq 0.05)$ during storage and 
significant interactions existed between treatments and storage days. Initially $\mathrm{pH}$ increased significantly $(\mathrm{P} \leq 0.05)$ from $6.45 \pm 0.01$ to $6.65 \pm 0.02,6.47 \pm 0.02$ to $6.61 \pm 0.02,6.46 \pm 0.01$ to $6.56 \pm 0.02,6.45 \pm 0.02$ to $6.52 \pm 0.02$ from day 0 to day 7 and then decreased significantly $(\mathrm{P} \leq 0.05)$ up to the end of the storage for control, T-1, T-2 and T-3. Although, the increase was found in all samples up to day 7 but, increase was not as rapid as control. However, after $7^{\text {th }}$ day of storage, significant reduction $(\mathrm{P} \leq 0.05)$ in $\mathrm{pH}$ values was observed in all samples with storage time. This could be attributed to the build up of lactic acid due to augmentation of lactic acid bacteria resulting in decline in the $\mathrm{pH}$ values.

\section{TBARS}

Increase in storage period leads to development of volatile metabolites due to oxidation of fat in the aerobic storage (Yadav and Sharma 2008). Hence as expected, increase in TBARS values of all the products was observed with increase in storage days, however rate of increase was comparatively slower $(\mathrm{P} \leq 0.05)$ in case of $\mathrm{T}-3$ products, followed by $\mathrm{T}-2$ and $\mathrm{T}-1$ respectively, indicating more oxidative stability of higher EO concentration treatment products (Table 4). However, in control, the values ranged from $0.572 \pm 0.005$ to $1.057 \pm 0.006 \mathrm{mg}$ malonaldehyde/kg. During storage, increase in TBARS followed the pattern as $\mathrm{T}-3<\mathrm{T}$ $2<\mathrm{T}-1<$ Control.

\section{DPPH free radical scavenging activity}

On day 0 , the activity was comparable among control and T-1 and T-2 and T-3 (Table 4). However, the activity of control was lower than treated products with storage and control products showed most rapid rate of fall of DPPH activity in comparison to other treated products. T-3 showed least decrease in DPPH activity followed by T-2, T-1 and control.

\section{Microbiological characteristics}

\section{Total plate count}

During storage, significant increase in TPC was observed in both control and treatment products at each interval of storage period. However, treatment products showed slower rate of increase in TPC than control. No coliforms were detected in any of the samples during the given period of storage studies. Psychrophilic counts were not detected during initial periods of storage, however, were observed 7 days onwards. During storage period, significant increase $(\mathrm{P} \leq 0.05)$ in yeast and mould count was observed for control and treated products (Table 5).

\section{Sensory scores}

During storage the colour and appearance scores displayed a decreasing trend possibly due to the lipid and pigment oxidation. An increase in the TBARS value under aerobic storage has been correlated to decrease in the flavour scores (Tarladgis et al., 1960). Storage affects flavour scores in other meat products too (Kumar and Sharma 2004). The control, T-1, T-2 and T-3 products got spoiled on $21^{\text {st }}, 26^{\text {th }}, 26^{\text {th }}$ and $30^{\text {th }}$ day of storage, respectively, so were not sensory evaluated by the panelists (Table 6). The results indicated that the colour and appearance scores showed decreasing trend throughout the storage period. The flavor scores were comparable on day 0 , however the scores differed later on. The scores were comparable up to day 7 in treated products and then decreased at different pace. The texture scores were comparable in all and decreased during storage. The juiciness scores followed a decreasing trend throughout the storage period. A decrease in overall acceptability scores was expected because of decrease in scores of other attributes with the advancement of storage period. 
In terms of sensory scores, control received higher score every single time in terms of flavour but as the storage period increased the fermented taste due spoilage was more pronounced in the control. Meanwhile, the treatment samples did not exhibited the sour taste until very long. But the higher concentration of E.O. ( $0.250 \%$ and $0.50 \%)$ made the product pungent and not acceptable in sensory attributes. But, a lower level $(0.125 \%)$ was accepted well by the consumer panel.

No effect on proximate composition was in agreement with Dzudie et al., (2004) who had also reported similar results in essential oil incorporated beef patties.

The increase in $\mathrm{pH}$ reveal the extent of meat spoilage due to breakdown of proteins producing free amino acids which led to ammonia and amines formation, compounds of alkaline reaction (Karabagiaset al., 2011). The results were in harmony with Siewe et al., (2015); Kumar and Tanwar (2011). It has also been reported by Kumar (2015) that pH of meat products with or without essential oil increased during storage period, although $\mathrm{pH}$ increased slowly in essential oil treated products.

However, after $7^{\text {th }}$ day of storage, significant reduction $(\mathrm{P} \leq 0.05)$ in $\mathrm{pH}$ values with storage time could be attributed to the accumulation of lactic acid due to growth of lactic acid bacteria resulted in decreased $\mathrm{pH}$ values. Similar observations were reported by Wang et al., (2013); Karabacak and Bozkurt (2008); Jayawardana et al., (2015).

However, lower $\mathrm{pH}$ in treatment products in comparison to control possibly be due to the existence of phenolics groups in essential oils (Burt, 2004; Jaysena and Jo, 2013). During storage, increase in TBARS value was might be due to the increase in fat oxidation and production of volatile metabolites during aerobic storage (Yadav and Sharma, 2008). Presence of polyphenols in oregano essential oil which react with free radicals and hydroxyls transforming them into more stable forms (Jayawardana et al., 2015) could have been the reason for their increased stability. Siewe et al., (2015) encountered similar findings with $0.2 \%$ clove essential oil in beef patties. The higher incorporation level showed its strong antioxidant activity in the product resulted in significantly lower $(\mathrm{P} \leq 0.05)$ TBARS value $(0.775 \pm 0.006)$ even on the $26^{\text {th }}$ day of storage.

The DPPH activity of the samples revealed that highly significant difference $(\mathrm{P} \leq 0.05)$ between treatments and storage days was observed. The control product exhibited DPPH activity on day 0 , which might be due to native bioactive compounds of meat and spices with known antioxidant effect added in the formulation.

However, with storage, the control products showed most rapid rate of fall of DPPH activity which might be due to less inhibition of free radicals due to absence of phenolics compounds. T-3 showed least decrease in DPPH activity followed by $\mathrm{T}-2, \mathrm{~T}-1$ and control which was probably due to higher phenolic compounds in comparison to other. Phenolic compounds act as antioxidants by several mechanisms such as the sequestration of free radicals, hydrogen donation, metallic ion chelation or even acting as substrate of radicals such as superoxide or hydroxyl (AlMamary et al., 2002).

Increase in SPC with storage period was expected because meat products act as excellent growth media for microbes. Antimicrobial activity of the essential oils is due to the presence of hydroxyl groups. Similar results were obtained by Siewe et al., (2015) who reported significant decrease in 
bacterial load due to addition of essential oil in meat products.

The antimicrobial mechanism of action of these constituents is generally considered to be the disturbance of cytoplasmic membrane, disruption of proton motive force, electron flow, active transport and coagulation of cell contents (Leite et al., 2006). Absence of psychrophilic counts in the products during initial periods of storage might be due to slow log phase as a result of abridged metabolic rate due to abrupt change in physical environment (Sharma et al., 2013). The counts increased with increase in storage period, but lower counts of treated products could be attributed to phenolic groups of oregano essential oil. Variation in incorporation level of oregano essential oil could be the reason for varying antimicrobial effect of the treatments.

Absence of coliforms was a sign of the hygienic practices and conditions adapted during the processing and handling of the products as well as the high temperature treatment employed during cooking (Kumar and Sharma, 2004).The absence of yeast and mould count in early days was might be due to unfavourable conditions for their growth such as high $\mathrm{pH}$, lower temperature and high moisture content.

Table.1 Formulation of chicken patties

\begin{tabular}{|l|l|}
\hline Ingredients & Percentage (\%) \\
\hline Lean meat & 70 \\
\hline Ice Flakes & 10 \\
\hline Vegetable Oil & 10 \\
\hline Refined Wheat Flour(Maida) & 3.2 \\
\hline Condiments & 3.5 \\
\hline Sodium Chloride & 1.8 \\
\hline Spice mix & 1 \\
\hline STPP & 0.5 \\
\hline Sodium nitrite(ppm) & 150 \\
\hline
\end{tabular}

Table.2 Effect of oregano essential oil on the proximate composition of aerobically packaged chicken patties (Mean \pm S.E.)

\begin{tabular}{|l|c|c|c|c|}
\hline Composition/Treatments & Control & T-1 & T-2 & T-3 \\
\hline Moisture (\%) & $51.33 \pm 0.67$ & $51.76 \pm 0.22$ & $51.47 \pm 0.88$ & $51.07 \pm 0.79$ \\
\hline Fat (\%) & $20.08 \pm 0.67$ & $20.13 \pm 0.45$ & $20.11 \pm 0.26$ & $20.07 \pm 0.45$ \\
\hline Protein (\%) & $16.69 \pm 0.59$ & $16.69 \pm 0.69$ & $16.70 \pm 0.61$ & $16.68 \pm 1.64$ \\
\hline Ash (\%) & $3.35 \pm 0.19$ & $3.36 \pm 0.15$ & $3.37 \pm 0.50$ & $3.36 \pm 0.24$ \\
\hline
\end{tabular}

$\mathrm{n}=6 ; \mathrm{NE}=$ not estimated; Control= chicken patties without essential oil, $\mathrm{T}-1=0.125 \%, \mathrm{~T}-2=0.25 \%, \mathrm{~T}-3=0.5 \%$. 
Table.3 Effect of oregano essential oil on the $\mathrm{pH}$ of aerobically packaged chicken patties during refrigerated storage (Mean \pm S.E.)

\begin{tabular}{|c|c|c|c|c|c|c|}
\hline Treatments/Days & Day 0 & Day 7 & Day 14 & Day 21 & Day 26 & Day 30 \\
\hline Control & $6.47 \pm 0.01^{\mathrm{cl}}$ & $6.65 \pm 0.02^{\mathrm{d} 3}$ & $6.35 \pm 0.01^{\mathrm{b} 1}$ & $6.16 \pm 0.01^{\mathrm{a} 1}$ & $\mathrm{NE}$ & $\mathrm{NE}$ \\
\hline T-1 & $6.47 \pm 0.02^{\mathrm{cl}}$ & $6.61 \pm 0.02^{\mathrm{ad} 23}$ & $6.49 \pm 0.01^{\mathrm{c} 23}$ & $6.35 \pm 0.01^{\mathrm{b} 2}$ & $6.19 \pm 0.01^{\mathrm{a} 1}$ & $\mathrm{NE}$ \\
\hline T-2 & $6.46 \pm 0.01^{\mathrm{cl}}$ & $6.56 \pm 0.02^{\mathrm{ae} 12}$ & $6.51 \pm 0.01^{\mathrm{d} 3}$ & $6.38 \pm 0.01^{\mathrm{b} 23}$ & $6.22 \pm 0.01^{\mathrm{a} 2}$ & $\mathrm{NE}$ \\
\hline T-3 & $6.45 \pm 0.02^{\mathrm{d} 1}$ & $6.52 \pm 0.02^{\mathrm{el}}$ & $6.44 \pm 0.01^{\mathrm{d} 2}$ & $6.40 \pm 0.01^{\mathrm{c} 3}$ & $6.32 \pm 0.01^{\mathrm{b} 3}$ & $6.24 \pm 0.01^{\mathrm{a}}$ \\
\hline
\end{tabular}

$\mathrm{n}=6 ; \mathrm{NE}=$ not estimated; Control $=$ chicken patties without essential oil, $\mathrm{T}-1=0.125 \%, \mathrm{~T}-2=0.25 \%, \mathrm{~T}-3=0.5 \%$.

$*$ Mean \pm S.E. bearing different superscripts in a row-wise (alphabet) and column wise (numeral) differ significantly $(\mathrm{P} \leq 0.05)$

Table.4 Effect of oregano essential oil on the DPPH of aerobically packaged chicken patties during refrigerated storage (Mean \pm S.E.)

\begin{tabular}{|c|c|c|c|c|c|c|}
\hline Treatments/Days & Day 0 & Day 7 & Day 14 & Day 21 & Day 30 \\
\hline Control & $30.19 \pm 0.33^{\mathrm{d} 1}$ & $26.81 \pm 0.42^{\mathrm{c} 1}$ & $21.89 \pm 0.46^{\mathrm{b} 1}$ & $18.82 \pm 0.31^{\mathrm{a} 1}$ & $\mathrm{NE}$ \\
\hline T-1 & $30.56 \pm 0.33^{\mathrm{e} 1}$ & $27.88 \pm 0.24^{\mathrm{d} 12}$ & $24.84 \pm 0.18^{\mathrm{c} 2}$ & $23.31 \pm 0.24^{\mathrm{b} 2}$ & $21.03 \pm 0.18^{\mathrm{a} 1}$ \\
\hline T-2 & $30.97 \pm 0.10^{\mathrm{e} 12}$ & $28.92 \pm 0.26^{\mathrm{d} 2}$ & $26.32 \pm 0.26^{\mathrm{c} 3}$ & $24.611 \pm 0.25^{\mathrm{b} 3}$ & $22.04 \pm 0.31^{\mathrm{a} 2}$ \\
\hline T-3 & $31.88 \pm 0.13^{\mathrm{f} 2}$ & $30.74 \pm 0.19^{\mathrm{e} 3}$ & $27.88 \pm 0.20^{\mathrm{d} 4}$ & $26.71 \pm 0.27^{\mathrm{c} 4}$ & $25.34 \pm 0.15^{\mathrm{b} 3}$ & $23.55 \pm 0.23^{\mathrm{a} 1}$ \\
\hline
\end{tabular}

$\mathrm{n}=6 ; \mathrm{NE}=$ not estimated; Control= nuggets without essential oil, $\mathrm{T}-1=0.125 \%, \mathrm{~T}-2=0.25 \%, \mathrm{~T}-3=0.5 \%$.

$*$ Mean \pm S.E. bearing different superscripts in a row-wise (alphabet) and column wise (numeral) differ significantly $(\mathrm{P} \leq 0.05)$ 
Table.5 Effect of oregano essential oil on the microbial quality of aerobically packaged chicken patties during refrigerated storage $(M e a n \pm$ S.E.)

\begin{tabular}{|c|c|c|c|c|c|c|}
\hline Treatments/Days & Day 0 & Day 7 & Day 14 & Day 21 & Day 26 & Day 30 \\
\hline \multicolumn{7}{|c|}{ SPC $\left(\log _{10} \mathbf{c f u} / \mathrm{g}\right)$} \\
\hline Control & $1.95 \pm 0.02^{\mathrm{a} 1}$ & $2.95 \pm 0.01^{\mathrm{b} 4}$ & $4.09 \pm 0.02^{c 4}$ & $5.03 \pm 0.01^{\mathrm{d} 3}$ & $\mathrm{NE}$ & $\mathrm{NE}$ \\
\hline T-1 & $1.94 \pm 0.02^{\mathrm{a} 1}$ & $2.83 \pm 0.01^{\mathrm{b} 3}$ & $3.98 \pm 0.01^{\mathrm{c} 3}$ & $4.88 \pm 0.02^{\mathrm{d} 23}$ & $5.08 \pm 0.01^{\mathrm{e} 3}$ & $\mathrm{NE}$ \\
\hline T-2 & $1.93 \pm 0.02^{\mathrm{a} 1}$ & $2.74 \pm 0.01^{\mathrm{b} 2}$ & $3.87 \pm 0.04^{\mathrm{c} 2}$ & $4.71 \pm 0.03^{\mathrm{d} 2}$ & $4.98 \pm 0.02^{\mathrm{e} 2}$ & $\mathrm{NE}$ \\
\hline T-3 & $1.93 \pm 0.02^{\mathrm{a} 1}$ & $2.65 \pm 0.01^{\mathrm{bl}}$ & $3.59 \pm 0.04^{\mathrm{cl}}$ & $4.14 \pm 0.08^{\mathrm{d} 1}$ & $4.68 \pm 0.04^{\mathrm{e} 1}$ & $5.02 \pm 0.02^{\mathrm{f1}}$ \\
\hline \multicolumn{7}{|c|}{ Psychrophilic $\left(\log _{10} \mathrm{cfu} / \mathrm{g}\right)$} \\
\hline Control & ND & ND & $1.32 \pm 0.14^{\mathrm{a}}$ & $1.61 \pm 0.08^{\mathrm{bl}}$ & $\mathrm{NE}$ & $\mathrm{NE}$ \\
\hline T-1 & ND & ND & ND & $1.30 \pm 0.10^{\mathrm{a} 1}$ & $1.52 \pm 0.13^{\mathrm{a} 1}$ & $\mathrm{NE}$ \\
\hline T-2 & ND & ND & ND & $1.30 \pm 0.14^{\mathrm{a} 1}$ & $1.48 \pm 0.11^{\mathrm{b} 1}$ & $\mathrm{NE}$ \\
\hline T-3 & ND & ND & ND & ND & $1.22 \pm 0.10^{\mathrm{a} 1}$ & $1.45 \pm 0.07^{\mathrm{b}}$ \\
\hline \multicolumn{7}{|c|}{ Coliform count $\left(\log _{10} \mathrm{cfu} / \mathrm{g}\right)$} \\
\hline Control & ND & ND & ND & ND & ND & ND \\
\hline T-1 & ND & ND & ND & ND & ND & ND \\
\hline T-2 & ND & ND & ND & ND & ND & ND \\
\hline T-3 & ND & ND & ND & ND & ND & ND \\
\hline \multicolumn{7}{|c|}{ Yeast and mould count $\left(\log _{10} \mathrm{cfu} / \mathrm{g}\right)$} \\
\hline Control & ND & $1.33 \pm 0.05^{\mathrm{a} 1}$ & $1.60 \pm 0.08^{\mathrm{b} 3}$ & $1.82 \pm 0.07^{\mathrm{b} 3}$ & $\mathrm{NE}$ & $\mathrm{NE}$ \\
\hline T-1 & ND & $1.33 \pm 0.05^{\mathrm{a} 1}$ & $1.48 \pm 0.08^{\mathrm{ab} 23}$ & $1.63 \pm 0.07^{\mathrm{bc} 23}$ & $1.77 \pm 0.03^{\mathrm{c} 2}$ & NE \\
\hline T-2 & ND & ND & $1.23 \pm 0.08^{\mathrm{a} 12}$ & $1.40 \pm 0.06^{\mathrm{ab} 12}$ & $1.54 \pm 0.03^{\mathrm{cl}}$ & $\mathrm{NE}$ \\
\hline T-3 & ND & ND & $1.15 \pm 0.08^{\mathrm{a} 1}$ & $1.30 \pm 0.07^{\mathrm{ab} 1}$ & $1.49 \pm 0.03^{\mathrm{bcl}}$ & $1.68 \pm 0.02^{\mathrm{cl}}$ \\
\hline
\end{tabular}

$\mathrm{n}=6 ; \mathrm{NE}=$ not estimated; $\mathrm{ND}=$ not detected; Control= nuggets without essential oil, $\mathrm{T}-1=0.125 \%, \mathrm{~T}-2=0.25 \%, \mathrm{~T}-$ $3=0.5 \%$.

*Mean \pm S.E. bearing different superscripts in a row-wise (alphabet) and column wise (numeral) differ significantly $(\mathrm{P} \leq 0.05)$ 
Table.6 Effect of oregano essential oil on the sensory attributes of aerobically packaged chicken patties during refrigerated storage (Mean \pm S.E.)

\begin{tabular}{|c|c|c|c|c|c|c|}
\hline Treatments/Days & Day 0 & Day 7 & Day 14 & Day 21 & Day 26 & Day 30 \\
\hline \multicolumn{7}{|c|}{ Colour and appearance } \\
\hline Control & $7.43 \pm 0.03^{c}$ & $7.36 \pm 0.05^{\mathrm{ab}}$ & $7.23 \pm 0.04^{\mathrm{a}}$ & NE & NE & $\mathrm{NE}$ \\
\hline T-1 & $7.44 \pm 0.04^{c}$ & $7.37 \pm 0.05^{\mathrm{bc}}$ & $7.24 \pm 0.04^{\mathrm{ab}}$ & $7.13 \pm 0.04^{\mathrm{a}}$ & $\mathrm{NE}$ & $\mathrm{NE}$ \\
\hline T-2 & $7.46 \pm 0.03^{b}$ & $7.40 \pm 0.05^{b}$ & $7.25 \pm 0.04^{\mathrm{a}}$ & $7.16 \pm 0.04^{\mathrm{a}}$ & NE & $\mathrm{NE}$ \\
\hline T-3 & $7.46 \pm 0.04^{\mathrm{d}}$ & $7.40 \pm 0.04^{\text {cd }}$ & $7.26 \pm 0.04^{\mathrm{bc}}$ & $7.19 \pm 0.04^{b}$ & $6.88 \pm 0.03^{\mathrm{a}}$ & $\mathrm{NE}$ \\
\hline \multicolumn{7}{|c|}{ Flavour } \\
\hline Control & $7.40 \pm 0.05^{\mathrm{c} 2}$ & $7.29 \pm 0.05^{\mathrm{b} 2}$ & $7.13 \pm 0.03^{\mathrm{a} 2}$ & NE & NE & $\mathrm{NE}$ \\
\hline T-1 & $7.40 \pm 0.04^{\mathrm{c} 2}$ & $7.30 \pm 0.03^{\mathrm{c} 2}$ & $7.16 \pm 0.03^{\mathrm{b} 2}$ & $6.82 \pm 0.04^{\mathrm{a} 1}$ & $\mathrm{NE}$ & $\mathrm{NE}$ \\
\hline T-2 & $7.38 \pm 0.03^{\mathrm{c} 2}$ & $7.28 \pm 0.04^{\mathrm{c} 2}$ & $7.15 \pm 0.03^{\mathrm{b} 2}$ & $6.81 \pm 0.04^{\mathrm{a} 1}$ & $\mathrm{NE}$ & $\mathrm{NE}$ \\
\hline T-3 & $7.21 \pm 0.03^{\mathrm{d} 1}$ & $7.12 \pm 0.03^{\mathrm{d} 1}$ & $6.98 \pm 0.02^{\mathrm{cl}}$ & $6.74 \pm 0.03^{b 1}$ & $6.53 \pm 0.05^{\mathrm{a}}$ & $\mathrm{NE}$ \\
\hline \multicolumn{7}{|c|}{ Texture/Tenderness } \\
\hline Control & $7.46 \pm 0.03^{c}$ & $7.31 \pm 0.03^{b}$ & $7.06 \pm 0.03^{\mathrm{a}}$ & $\mathrm{NE}$ & $\mathrm{NE}$ & $\mathrm{NE}$ \\
\hline T-1 & $7.45 \pm 0.03^{d}$ & $7.30 \pm 0.03^{c}$ & $7.05 \pm 0.03^{b}$ & $6.83 \pm 0.05^{\mathrm{a}}$ & NE & $\mathrm{NE}$ \\
\hline T-2 & $7.44 \pm 0.03^{c}$ & $7.28 \pm 0.03^{\mathrm{c}}$ & $7.06 \pm 0.03^{b}$ & $6.84 \pm 0.05^{\mathrm{a}}$ & NE & $\mathrm{NE}$ \\
\hline T-3 & $7.44 \pm 0.03^{d}$ & $7.28 \pm 0.03^{\mathrm{d}}$ & $7.06 \pm 0.03^{c}$ & $6.85 \pm 0.05^{\mathrm{b}}$ & $6.55 \pm 0.03^{\mathrm{a}}$ & $\mathrm{NE}$ \\
\hline \multicolumn{7}{|c|}{ Juiciness } \\
\hline Control & $7.24 \pm 0.02^{c}$ & $7.10 \pm 0.03^{b}$ & $6.85 \pm 0.06^{\mathrm{a}}$ & NE & $\mathrm{NE}$ & $\mathrm{NE}$ \\
\hline T-1 & $7.23 \pm 0.03^{d}$ & $7.10 \pm 0.03^{c}$ & $6.83 \pm 0.06^{b}$ & $6.70 \pm 0.06^{\mathrm{a}}$ & $\mathrm{NE}$ & $\mathrm{NE}$ \\
\hline T-2 & $7.24 \pm 0.04^{d}$ & $7.09 \pm 0.03^{c}$ & $6.85 \pm 0.05^{b}$ & $6.73 \pm 0.04^{\mathrm{a}}$ & NE & $\mathrm{NE}$ \\
\hline $\mathbf{T}-\mathbf{3}$ & $7.23 \pm 0.05^{\mathrm{e}}$ & $7.10 \pm 0.04^{\mathrm{d}}$ & $6.87 \pm 0.04^{\mathrm{c}}$ & $6.74 \pm 0.05^{\mathrm{b}}$ & $6.62 \pm 0.03^{a}$ & $\mathrm{NE}$ \\
\hline \multicolumn{7}{|c|}{ Overall acceptability } \\
\hline Control & $7.42 \pm 0.04^{\mathrm{c} 2}$ & $7.30 \pm 0.03^{\mathrm{b} 2}$ & $7.05 \pm 0.02^{\mathrm{a} 2}$ & NE & NE & $\mathrm{NE}$ \\
\hline T-1 & $7.41 \pm 0.03^{\mathrm{d} 2}$ & $7.30 \pm 0.03^{\mathrm{c} 2}$ & $7.06 \pm 0.03^{\mathrm{b} 2}$ & $6.83 \pm 0.03^{\mathrm{a} 2}$ & $\mathrm{NE}$ & $\mathrm{NE}$ \\
\hline T-2 & $7.41 \pm 0.04^{\mathrm{d} 2}$ & $7.28 \pm 0.04^{\mathrm{c} 2}$ & $7.05 \pm 0.03^{\mathrm{b} 2}$ & $6.81 \pm 0.02^{\mathrm{al}}$ & NE & $\mathrm{NE}$ \\
\hline T-3 & $7.12 \pm 0.04^{\mathrm{d} 1}$ & $6.90 \pm 0.03^{\mathrm{c} 1}$ & $6.59 \pm 0.03^{\mathrm{b} 1}$ & $6.46 \pm 0.03^{b 1}$ & $6.24 \pm 0.06^{\mathrm{a}}$ & $\mathrm{NE}$ \\
\hline
\end{tabular}

$\mathrm{n}=18 ; \mathrm{NE}=$ not estimated; $\mathrm{ND}=$ not detected; Control= chicken patties without essential oil, $\mathrm{T}-1=0.125 \%$, $\mathrm{T}-$ $2=0.25 \%, \mathrm{~T}-3=0.5 \%$.

$*$ Mean \pm S.E. bearing different superscripts in a row-wise (alphabet) and column wise (numeral) differ significantly $(\mathrm{P} \leq 0.05)$.

Colour and appearance scores showed decreasing trend throughout the storage which was might be due to pigment and lipid oxidation. A gradual decline in flavor scores might be due to expected loss of volatile flavor components on storage of meat products. The progressive decrease in flavor scores could be correlated to increase in
TBARS values in the meat products (Tarladgis et al., 1960) under aerobic storage. A decrease in flavor scores during storage was also reported by Kumar and Sharma (2004). The decline in texture might be attributed to proteolytic and disulphide bonds changes (Santamaria et al., 1992) taking place with progress of storage period. Matlock et 
al., (1984) and Ho et al., (1997) also reported decrease in tenderness of products with the progress of refrigerated storage. The decrease in juiciness scores was might be due to loss of moisture occurring through moisture permeable LDPE film used for packaging during storage period. Kumar and Sharma (2004) also reported decline in juiciness scores of pork patties during storage. The decrease in overall acceptability scores of the other meat products during storage has been reported by various authors such as Cegielska-Radziejewska et al., (2008) in poultry meat products, Biswas et al., (2011) in duck patties and Zargar et al., (2014) in chicken sausages.

In conclusion, out of the three essential oil concentrations, treatment $1(0.125 \%)$ received maximum acceptance and it has an enhancing effect over the storage life of the chicken patties. Although the higher concentrations of the oil showed exceptional antimicrobial and antioxidant properties and gave a longer shelf life, they failed to impress the sensory panel which rejected the treatments at once. Thus, it can be concluded that oregano essential oil is effective in enhancing the shelf life of chicken patties but acceptance level due to its pungency is very low.

\section{References}

APHA. (1992). Compendium of methods for the microbiological examination of foods. $3^{\text {rd }}$ edition. American Public Health Association, Washington, DC.

Bourre, J.M., Where to find omega-3 fatty acids and how feeding animals with diet enriched in omega-3 fatty acids to increase nutritional value of derived products for human: What is actually useful?, (2005) Journal of Nutrition, Health and Aging, 9 (4), pp. 232-242.

Mielnick M.B., E. Olsen, G. Vogt, D. Adeline, G. Skrede Grape seed extract as antioxidant in cooked, cold stored turkey meat LWT Food Science and Technology, 39 (2006), pp. 191-198

Barlow S.M., Toxicological aspects of antioxidants used as food additives, B.J.F. Hudson (Ed.), Food antioxidants, Elsevier, London (1990), pp. 253-307

Branen A.L., Toxicology and biochemistry of butylated hydroxyanisole and butylated hydroxytoluene, Journal of American Oil Chemical Society, 52 (1975), pp. 59-63

Chan H.W.S., Autoxidation of unsaturated lipids, Academic Press, London (1987)

Namiki M., Antioxidants / antimutagens in food, Critical Reviews in Food Science \& Nutrition, 29 (1990), pp. 273-300

Pokorny J., Natural antioxidant for food use, Trends in Food Science Technology, 9 (1991), pp. 223-227

Koleva I.I., van Beek T.A., Linssen J.P.H., Groot A. de, Evstatieva L.N., Screening of plant extracts for antioxidant activity: a comparative study on three testing methods, Phytochemical Analysis, 13 (2002), pp. 8-17

Milos, M., Mastelić, J., Jerkovic, I., \& Katalinic, V. (2000). Chemical composition and antioxidant activity of the essential oil of oregano (Origanum vulgare L.) grown wild in Croatia. Rivista Italiana Eppos, Jan., 617-624.

Chouliara E., Karatapanis A., Savvaidis I.N., Kontominas M.G., Combined effect of oregano essential oil and modified atmosphere packaging on shelf-life extension of fresh chicken breast meat, stored at $4{ }^{\circ} \mathrm{C}$, Food Microbiology Volume 24, Issue 6, September 2007, Pages 607-617

Tsigarida E., Skandamis P., Nychas G-J.E., Behaviour of Listeria monocytogenes and autochthonous flora on meat stored under aerobic, vacuum and modified atmosphere packaging 
conditions with or without the presence of oregano essential oil at $5{ }^{\circ} \mathrm{C}$, Journal of Applied Microbiology Volume 89, Issue 6December 2000 Pages 901-909

Kumar, S. 2015. Quality evaluation of mutton nuggets incorporated with flaxseed flour and essential oils. M.V.Sc. thesis, Indian Veterinary Research Institute.

Kumar, M. and Sharma, B. D. (2004). The storage stability and textural, physicochemical and sensory quality of low-fat ground pork patties with carrageenan as fat replacer. International Journal of Food Science and Technology, 39, 3142.

Sharma, H., Sharma, B. D., Mendiratta, S. K.,
Talukder, S. and Ramasamy, G. (2013). Efficacy of flaxseed flour as bind enhancing agent on the quality of extended restructured mutton chops. Asian Australasian Journal of Animal Sciences, 27, 247-255.

Yadav, S. and Sharma, D. P. (2008). Effect of enrobing with and without preservatives on the quality characteristics of chicken patties. Indian Journal of Poultry Science, 43, 333-38.

Karabagias, I., Badeka, A., Kontominas, M. G. (2011). Shelf life extension of lamb meat using thyme or oregano essential oils and modified atmosphere packaging. Meat Science 88, 109-116.

\section{How to cite this article:}

Neha Thakur, S.K. Mendiratta, Geeta Chauhan, Arvind Soni and Ravi Kant Agrawal. 2019. Antioxidant and Antimicrobial Effect of Oregano Essential Oil on Shelf-Life of Chicken Patties. Int.J.Curr.Microbiol.App.Sci. 8(02): 3076-3087.

doi: https://doi.org/10.20546/ijcmas.2019.802.360 